\title{
DISCHARGE OF ORGANIC AND BIOGENIC SUBSTANCES FROM SMALL RIVERS OF KALININGRAD REGION IN THE BALTIC SEA
}

\author{
Tatiyana Bernikova \\ Anna Malyavkina \\ Nadeja Nagornova \\ Kaliningrad State Technical University, Russia
}

\begin{abstract}
The Pregolja and the Neman (its basin is situated within four states) rivers are the largest sources of load on the Vistula (Kaliningrad) and the Curonian lagoons from Kaliningrad Region. Complex ecological researches of the small rivers were accomplished in 1993-1999, besides the hydrological data bank was replenished due to researches in June 2001-July 2006.

Analysis of monthly average has shown that the load from each studied river (with rare exception only) is directly proportional to size of the basin and to the total average runoff. The condition of these rivers reflects the ecological situation in the significant river water regime phase area. Hydrochemical parameters reflect a present picture of pollution and saprobiological parameters characterize a situation in the reservoir for some period of time interval before researches. The load from the river is connected with the phases of the riverflow regimes substantially and its different parameters can increase or decrease in accordance with the changes of underground and superficial nutrition ratio and with the seasonal prevalence of the hydrobionts' vital functions.
\end{abstract}

Thus, one of the criteria for estimating the ecosystem pollution may be the limit; load from the river is higher which ceases to be than the exceeding, this means that the load from river is not proportional to the area of its reservoir, i.e. the river practically looses ability to autopurification.

Specific load, i.e. monthly average load from the area unit of the river basin was calculated and analyzed. The results have estimated the contribution of each river eutrophication of the receiving water. In particular, load from the Mamonovka and the Prokhladnaya river (their basins are partly located in the territory of Poland) concerning the majority of river parameters was in several times (sometimes in multiple and more) higher than the other rivers. It was revealed, that the load from the river was substantially connected with and different parameters can increase or decrease pursuant to changes in ratio between underground and surface recharge and seasonality of.

\section{KEYWORDS}

Small river; Hydrochemical parameters; River water regime phases; Ecosystem pollution hydrobionts' activity. 


\section{INTRODUCTION}

Geologic-geomorphological and climatic conditions of the Kaliningrad region of Russian Federation contribute to excessive supply of water resources. Approximately $40 \%$ of the territory of the Kaliningrad region is occupied with the Pregoljas river basin with largest confluents and with the subbasins of the Angrapy and Instruch rivers (confluence of these two rivers form the Pregolja river).

The Pregolja and the Neman (its basin is situated within four states) rivers are the largest sources of load on the Vistula (Kaliningrad) and the Curonian lagoons from Kaliningrad Region. The first one runs over Russian territory, but its left confluents begin in Republic of Poland; the second one runs through the territories of three countries (Belarus, Lithuania and Russia), and one of the biggest confluent (Sheshupe river) springs from Poland. The extension of the Neman river is $937 \mathrm{~km}$, the Pregolja river (from the junction of rivers Angrapa and Instruch) - $123 \mathrm{~km}$, the annual runoff accordingly 25.1 and $1.4 \mathrm{~km}^{3}$. However, the overwhelming majority of water streams of Kaliningrad Region are small rivers (basin area less than $2000 \mathrm{~km}^{2}$, length of 10 up to $25-50 \mathrm{~km}$ ).

\section{OVERALL PERFORMANCE}

Almost all rivers in estuary of the Neman river at the Curonian lagoon are connected by canals, they form unified melioration system and belong to basin of Curonian lagoon. Other part of territory is occupied with river basins of the Mamonovka, the Prokhladnaya, the Nelma, the Primorskaya rivers, some small rivers, and also with subbasins of confluents of the Neman: the Tilga and the Sheshupe rivers. The rivers that flow from east and southern borders of the Kaliningrad region are transboundary.

Average slopes of rivers are less than 0.001 (in the river basin of the Sheshupe river - 0.0008 , in the estuary of the Neman - 0.0004, in the estuary of the Pregolja river - 0.0001).

The most part of the territory of the Kaliningrad region is drained. A great amount of rivers are transformed into the meliorative canals; also there are many drainage canals in the floodplain of rivers.

The areas at rivers outlets are regulated by the polder system. The particular place takes the system Pregolja - Deima (branch of the Pegolja river, entering the Curonian lagoon), where redistribution of drain depends on surging: winds of eastern direction increase the drain through the main river into the Kaliningrad lagoon, western winds - through the Deima river into the Curonian one.

Estuary parts of rivers are situated at the backwater of receiving basin. Beds of the rivers that are pouring into the sea, in the estuary area are shifting - shifts are up to $200 \mathrm{~m}$ and more.

\section{SMALL RIVERS}

By the value of basin area of small rivers can be conditionally subdivided into very small (less than $150 \mathrm{~km}^{2}$ - rivers Primorskaya and Chistaya have been inspected), middle-small (150-450 $\mathrm{km}^{2}$ rivers Zabava, Medvezhya, Zelenogradka, Bolshaya Moryanka, Nelma, Mamonovka) and simply small (more than $500 \mathrm{~km}^{2}$ river Prohladnaya has been inspected). Almost all of them drain a considerable area of agricultural lands, run near stock-raising complexes, 
through settlements, as a result of it their water can carry large amounts of organic and biogenic matters.

Basins of such rivers are contained under the large influence of local factors, therefore they reside considerable short-term changeability, quite often commensurable to seasonal variations (and sometimes exceeds it). That confirms, for example, results received in 1995 at the middle stream of river Zelenogradka after hot and dry weather on July 6 and after wet weather with heavy showers on 14 and 20 of July. River flow during first week increased almost two times, and then at $0.04 \mathrm{~m}^{3} / \mathrm{s}$ more. Approximately at the same value depth of river increased $(0.23 ; 0.40 ; 0.44 \mathrm{~m}), 1.5$ times increased distance at waterline $(1.8 ; 2.1$ and $2.9 \mathrm{~m})$. Discharge of river station, where the influence of affluent from lagoon begins, usually very insignificant $\left(0.02-0.06 \mathrm{~m}^{3} / \mathrm{s}\right)$ or zero (6 of July; 21 of August), 18 of October under strong wind down-stream increased (until $0.27 \mathrm{~m}^{3} / \mathrm{s}$ ). The fact that such sudden increase of discharge is caused mainly by run-down wind can be seen from the results, received at the same day at the beginnings of the river, which hadn't differed.

One more feature of small rivers is their limited self-purification capacity, as a result they become polluted, silted, degraded easily. At the same time, they cause some contribution in pollution of the Baltic Sea and, especially, its lagoons.

To fulfill rational water utilization activity in a basin of any river and optimal water resources management it's necessary to have systematized impartial information about the condition of water objects and water resources.

Each of this organizations fulfill functions, peculiar to it, at that time monitoring is organized, first of all, at water objects, having a great economical significance or being considerable pollution by sewage and diffuse drain from a territory of lodgment. At the same time overwhelming majority of small, especially the smallest, drainages turn not to be enveloped with the observation.

Taking into account these circumstances, the scientists of the Ichthyology and Ecology Department of Kaliningrad State Technical University in 1993 - 1999 have been realizing integrated study of hydrologic and hydrobiology features of small rivers; in following years (until the present time) the bank of hydrological and hydro chemical data is enriched with the results of observation in June - July.

\section{STUDY OF THE LOAD}

More than $95 \%$ of the total length of the rivers of Kaliningrad region is a share of the small rivers. Hydrological conditions of such rivers are characterised with a big variability and demand rather detailed study. Complex ecological researches of the small rivers (including the Mamonovka and Prokhladnaya which basins in part are located in Poland) were accomplished in 1993-1999. All the rivers were studied within some (4-6) months during several years which differ essentially both in the weather conditions and water content conditions of the rivers, within (4-6) months. The generalized characteristic of the received results is reported. Besides, the total load its monthly average values are calculated. The analysis of the received data has shown that the load from each river (with rare exception only) is directly proportional to the sizes of river basin and to the total average runoff. Hence, rivers' pollution distinctions were not so big to change their load to the sea essentially. For an estimation of the load independent on the total water catchment area, the specific load was calculated. It was got as quotient after division of monthly average total load into the basin 
area. The analysis of the received results has allowed to compare the load from each river more authentically and irrespectively of the terms the observation.

Despite of insufficient data, this paper attempts to estimate approximately the carrying-out of organic and biogenic matter into the sea by small rivers. To exclude to some degree an influence of short-term changeability on the results works at the rivers were planned in that way to inspect a river all along in the shortest possible time, during less than one light day.

Ranges (hydrological station) on rivers were situated from the beginning until the emptying into the sea with the expectation of uncovering and evaluating of influence of main sources of pollution. At some rivers it was succeed to fix faults of unrefined water or to detect an influence of emergency situations. Expeditional (as a raid) character of researches didn't allow organizing regular monthly observations, in winter time observations weren't held.

The total load from observed rivers on main indexes evaluates the total volume of carryingout of organic and biogenic matters into the Baltic sea, is calculated by using Equation 1:

$$
L=\sum_{i=1}^{n} C_{a_{i}} W_{a_{i}}
$$

$\mathrm{C}_{\mathrm{ai}}$, : normal concentration of substance in two successive probes;

$\mathrm{W}_{\mathrm{al}}$, volume of carrying-out in a period between selections of two successive probes;

$\mathrm{n}$, number of measurement.

The load of these rivers is usually linear to average water discharge and summary module of carrying-out. It illustrates the fact that the differences of polluting of every of the two rivers in periods of working on them were not so great to influence essentially the load. Based on this, one of criterion of pollution of river ecosystem can be considered that limit, higher of that the load from river stops to be proportional to above-mentioned indexes, i.e. river looses its ability of self-purification.

Hydrochemical parameters reflect a present picture of pollution and saprobiological parameters characterize a situation in the reservoir for some period of time interval before researches. The load from the river is connected with the phases of the river-flow regimes substantially and its different parameters can increase or decrease in accordance with the changes of an underground and superficial nutrition ratio and with the seasonal prevalence of the hydrobionts vital functions. Thus, one of the criteria for estimating the ecosystem pollution may be the limit; load from the river is higher which ceases to be than the exceeding, this means that the load from river is not proportional to the area of its reservoir, i.e. the river practically looses ability to autopurification.

Specific load, i.e. monthly average load from the area unit of the river basin was calculated and analyzed. The results have estimated the contribution of each river eutrophication of the receiving water. In particular, load from the Mamonovka and the Prokhladnaya river (their basins are partly located in the territory of Poland) concerning the majority of river parameters was in several times (sometimes in multiple and more) higher than the other rivers. It was revealed, that the load from the river was substantially connected with and different parameters can increase or decrease pursuant to changes in ratio between underground and surface recharge and seasonality of. 


\section{CONCLUSIONS}

Specificity of a geographical situation of the Kaliningrad region leads us to get participation in regional international systems of monitoring of an environment.

\section{REFERENCES}

[1] Alyokin, O.A., 1970. Fundamentals of Hydrochemistry. Gidrometeoizdat, Leningrad, $433 \mathrm{p}$.

[2] Atlas of Kaliningrad Region. 2002. Editor-in-chief Orlyonok V.V. Kaliningrad State University Publisher, CNIT, Kaliningrad, 276 p.

[3] Environment Protection. 1978. Reference Book. Sudostroeniye, Leningrad, 560 p.

[4] Lipin, A. N., 1950. Fresh Water and Water Life. AS of the USSR, Moscow, 347 p.

[5] Odum, E., 1975. Fundamental Ecology. Mir, Moscow, pp 236-382.

[6] Reference Book on Water Characteristics, Analysis Techniques and Water Treatment. 1980. Naukova Dumka, Kiev, 406 p. 